\section{DRUG THERAPY}

\author{
Alastair J.J. Wood, M.D., Editor
}

\section{OCTREOTIDE}

Steven W.J. Lamberts, M.D., Ph.D., Aart-Jan van der Lely, M.D., Ph.D., Wouter W. de Herder, M.D., Ph.D., and Leo J. Hofland, Ph.D.

\begin{abstract}
A PEPTIDE inhibiting the release of growth hormone was originally detected accidentally during studies of the distribution of growth hormone-releasing factor in the hypothalamus of rats. ${ }^{1}$ This peptide, called somatostatin, proved to be a cyclic peptide consisting of 14 amino acids. ${ }^{2}$ Subsequent work has considerably expanded this initially simple concept of somatostatin as a peptide whose main function is the regulation of growth hormone secretion. ${ }^{3}$ Today, somatostatin is best regarded as a phylogenetically ancient, multigene family of peptides with two important bioactive products: somatostatin-14 and somatostatin-28, the latter a congener of somatostatin-14 extended at the N-terminal., ${ }^{3,4}$

Like other peptide hormones, somatostatin is synthesized as part of a large precursor molecule that is rapidly cleaved into the prohormone form and processed enzymatically to yield several mature products. ${ }^{3,4}$ Somatostatin modulates neurotransmission in the central nervous system (as a neurotransmitter) and regulates the release of growth hormone and thyrotropin (as a neurohormone). It also has a regulatory role in the gastrointestinal tract, as well as in the exocrine and endocrine pancreas. When synthesized and released by endocrine and nerve cells in the gastrointestinal tract and pancreas, somatostatin acts in an autocrine, paracrine, or neuronal regulatory manner to inhibit glandular secretion, neurotransmission, smooth-muscle contractility, and absorption of nutrients. ${ }^{3,4}$ It also inhibits the function of activated immune cells. ${ }^{5}$
\end{abstract}

\section{SOMATOSTATIN RECEPTORS}

The various actions of somatostatin are mediated through specific membrane receptors, which have been demonstrated in various regions of the brain and leptomeninges, the anterior pituitary, the endocrine and exocrine pancreas, and the mucosa of the gastrointestinal tract, as well as in cells of the immune system., Five subtypes of the human somatostatin receptor have been cloned and characterized (Table 1). These subtypes,

From the Department of Medicine, Erasmus University, Rotterdam, the Netherlands. Address reprint requests to Dr. Lamberts at University Hospital Dijkzigt, 40 Dr. Molewaterplein, 3015 GD Rotterdam, the Netherlands.

Supported by the Dutch Cancer Society and the Dutch Foundation for Fundamental Research.

C1996, Massachusetts Medical Society. which are identical in 42 to 60 percent of their amino acid sequences, belong to a superfamily of receptors with seven membrane-spanning domains (Fig. 1A). ${ }^{8-11}$ The genes for these subtypes are located on different chromosomes, suggesting different functions in different organs (Table 1). Indeed, distinct but often overlapping patterns in the expression of these subtypes have been demonstrated. All five subtypes are functionally linked to adenylate cyclase through a coupling mechanism involving guanine nucleotide-binding $(\mathrm{G})$ protein (Fig. 1). ${ }^{21-23}$ Somatostatin-mediated activation of potassium channels and inhibition of voltage-dependent calcium channels are signal-transduction mechanisms that are reversed by pertussis toxin, although these two processes have not yet been demonstrated to be coupled to specific subtypes of somatostatin receptors. ${ }^{24}$ In the brain, somatostatin activates phospholipase $\mathrm{C}$ and phospholipase $\mathrm{A}$ and mobilizes calcium. ${ }^{25}$ Activation of somatostatin-receptor subtype 1 and subtype 2 results in the activation of tyrosine phosphatase, which is related to the antimitotic effects of somatostatin in some types of cells. ${ }^{20,26} \mathrm{In}$ addition, inhibition of cell proliferation is mediated by somatostatin-receptor subtype 5 , but through a different mechanism, probably involving changes in intracellular calcium mobilization. ${ }^{27}$

\section{Somatostatin Analogues}

Because of its ability to inhibit many functions of various organs, the expectation was that somatostatin would be of therapeutic value in clinical conditions involving the hyperfunction of these organs. ${ }^{28}$ Clinical use of somatostatin was hampered, however, by the need for intravenous administration, its short duration of action (a half-life in the circulation of less than three minutes), and the postinfusion rebound hypersecretion of hormones, such as growth hormone, insulin, and glucagon. ${ }^{28}$ Attempts have been made to synthesize somatostatin analogues that do not have these disadvantages. Octreotide, the first somatostatin analogue introduced for clinical use, inhibits the release of growth hormone, glucagon, and insulin in monkeys 45, 11, and 1.3 times more powerfully, respectively, than somatostatin- $14 .{ }^{29}$ Its elimination half-life after subcutaneous administration is two hours, and rebound hypersecretion of hormones does not occur. ${ }^{30,31}$ Two other cyclic analogues with slightly different activity profiles, vapreotide (RC160) and lanreotide (BIM-23014), ${ }^{20,32}$ are being tested in clinical trials in Europe.

All five somatostatin-receptor subtypes bind somatostatin-14 and somatostatin-28 with a similar high affinity, but there are differences in the binding affinities of the structural analogues of somatostatin (Table 1).12-14,23 Octreotide binds with a high affinity to somatostatinreceptor subtype 2 and subtype 5 and with a moderate affinity to subtype 3 but does not bind to subtypes 1 and 4. The binding characteristics of vapreotide and lanreotide are only slightly different, except with regard to subtype 4 (Table 1). Cyclic somatostatin analogues such as octreotide are more potent inhibitors of the release 
Table 1. Properties of the Five Cloned Subtypes of Human Somatostatin Receptors.*

\begin{tabular}{|c|c|c|c|c|c|}
\hline \multirow[t]{2}{*}{ PROPERTY } & \multicolumn{5}{|c|}{ SOMATOSTATIN RECEPTOR } \\
\hline & SUBTYPE 1 & SUBTYPE 2 & SUBTYPE 3 & SUBTYPE 4 & SUBTYPE 5 \\
\hline Chromosomal location & 14 & 17 & 22 & 20 & 16 \\
\hline G protein coupling & Yes & Yes & Yes & Yes & Yes \\
\hline $\begin{array}{l}\text { Effector system } \\
\text { Adenylate cyclase activity } \\
\text { Tyrosine phosphatase activity }\end{array}$ & $\begin{array}{l}\text { Reduced } \\
\text { Increased }\end{array}$ & $\begin{array}{l}\text { Reduced } \\
\text { Increased }\end{array}$ & $\begin{array}{c}\text { Reduced } \\
\text { Not investigated }\end{array}$ & $\begin{array}{c}\text { Reduced } \\
\text { Not investigated }\end{array}$ & $\begin{array}{c}\text { Reduced } \\
\text { Not investigated }\end{array}$ \\
\hline $\begin{array}{l}\mathrm{IC}_{50}(\mathrm{nM}) \dagger \\
\text { Somatostatin-14 } \\
\text { Somatostatin-28 } \\
\text { Octreotide } \\
\text { Vapreotide (RC-160) } \\
\text { Lanreotide (BIM-23014) }\end{array}$ & $\begin{aligned} & 1.1 \\
& 2.2 \\
> & 1000 \\
> & 1000 \\
> & 1000\end{aligned}$ & $\begin{array}{l}1.3 \\
4.1 \\
2.1 \\
5.4 \\
1.8\end{array}$ & $\begin{array}{c}1.6 \\
6.1 \\
4.4-35 \neq \\
30.9 \\
43.0\end{array}$ & $\begin{array}{c}0.5 \\
1.1 \\
>1000 \\
45.0 \\
66.0\end{array}$ & $\begin{array}{l}0.9 \\
0.07 \\
5.6 \\
0.7 \\
0.6\end{array}$ \\
\hline $\begin{array}{l}\text { Distribution in normal } \\
\text { human tissue } \S\end{array}$ & $\begin{array}{l}\text { Brain, lungs, stomach, jejunum, } \\
\text { kidneys, liver, and pancreas }\end{array}$ & Brain and kidneys & Brain and pancreas & Brain and lungs & $\begin{array}{l}\text { Brain, heart, adrenal glands, pla- } \\
\text { centa, pituitary, small intestine, } \\
\text { and skeletal muscle }\end{array}$ \\
\hline
\end{tabular}

*Data on the five subtypes were obtained from the following reports: subtypes 1 and 2, Yamada et al. ${ }^{8}$; subtype 3, Yamada et al. ${ }^{9}$; subtype 4, Bruno et al..$^{10}$; and subtype 5, O'Carroll et al. ${ }^{11}$ $\mathrm{fIC}_{50}$ denotes the concentration required for 50 percent inhibition of the binding of ${ }^{125}$ I-labeled somatostatin to the cloned subtype, as expressed in Chinese hamster-ovary or transformed African green-monkey COS kidney cells. Data were obtained from Patel and Srikant. ${ }^{12}$

†The value is reported as $4.4 \mathrm{nM}$ by Patel and Srikant, ${ }^{12} 31.6 \mathrm{nM}$ by Bruns et al..${ }^{13}$ and $35 \mathrm{nM}$ by Kubota et al. ${ }^{14}$

$\S$ Not all human tissues have been tested simultaneously. Data were obtained from Yamada et al.., Kaupmann et al., ${ }^{15}$ Rohrer et al.., ${ }^{16}$ Panetta et al., ${ }^{17}$ O'Carroll et al., ${ }^{18}$ and Bell and Reisine. ${ }^{19}$

of growth hormone than of the release of insulin, ${ }^{29}$ because the inhibition of growth hormone and insulin secretion is mediated by different somatostatin-receptor subtypes. ${ }^{33}$

We review the established indications for the use of somatostatin analogues in the treatment of various diseases and consider the potential use of these analogues for other disorders.

\section{Treatment of Hormone-Secreting Tumors}

\section{Acromegaly}

Most tumors originating from somatostatin target tissues have a high density of somatostatin receptors. This observation was first made with growth hormone-secreting pituitary tumors, most of which have a large number of receptors for somatostatin analogues. ${ }^{34}$ The presence of these receptors is required for the successful use of octreotide to control hormone secretion in patients with growth hormone-secreting pituitary tumors. The shortterm suppression of growth hormone in response to octreotide in a patient with acromegaly depends on the number of octreotide receptors on the pituitary tumor, ${ }^{34}$ and this early effect predicts the ultimate effect of longterm therapy on serum growth hormone and insulin-like growth factor I concentrations. ${ }^{35,36}$

The usual initial dose of octreotide is three daily subcutaneous injections of $100 \mu \mathrm{g}$ each. Both the number of injections and the dose, however, can be increased to achieve the maximal benefit. ${ }^{37}$ Among patients receiving 300 to $600 \mu \mathrm{g}$ of octreotide daily, up to 90 percent have suppressed serum growth hormone concentrations, over half have serum growth hormone concentrations of less than $5 \mu \mathrm{g}$ per liter, and about 70 percent have normal serum insulin-like growth factor I concentrations. ${ }^{36-38}$ A dose above $600 \mu \mathrm{g}$ per day rarely has additional effects. ${ }^{37,38}$ Overall, in comparative studies in a group of patients with acromegaly, octreotide was more effective than bromocriptine ${ }^{39}$; some patients have a bet- ter response to the combination of octreotide and bromocriptine than to either drug alone. ${ }^{40}$ The size of the tumor is reduced in about half the patients treated with octreotide..$^{35,37,38}$ The mechanism of tumor shrinkage is probably a (reversible) decrease in the size of individual tumor cells. ${ }^{38}$

Octreotide is particularly effective in reducing the headaches that are often associated with acromegaly, an effect that may be mediated by opioid receptors. ${ }^{3}$ Other symptoms of acromegaly, including joint pain, excessive perspiration, cardiomyopathy, and sleep apnea, are reduced or eliminated in most patients, and in many patients, the subjective clinical benefits of octreotide therapy are greater than the decreases in serum growth hormone and insulin-like growth factor I concentrations. Octreotide may also directly decrease growth hormone-stimulated production of insulin-like growth factor I. Increased serum prolactin concentrations, as well as galactorrhea or (secondary) amenorrhea, often resolve during treatment with octreotide in patients with acromegaly who have pituitary adenomas secreting both growth hormone and prolactin. ${ }^{41}$

Thus, octreotide is a rapidly acting and effective therapy for the majority of patients with acromegaly. Patients who have undergone an unsuccessful transsphenoidal operation or are awaiting the therapeutic effect of external pituitary irradiation are candidates for treatment with octreotide. Because growth hormone-secreting tumors in elderly patients are also highly sensitive to octreotide, it can be recommended as a primary treatment for such patients. ${ }^{42,43}$

The benefits of octreotide in the treatment of patients with acromegaly must be weighed against its adverse effects (discussed below). There have been no reports of the loss of the suppressive effect of octreotide on growth hormone secretion in patients with acromegaly, even after more than 10 years of uninterrupted therapy. ${ }^{38,43}$ The high cost of treatment with octreotide 


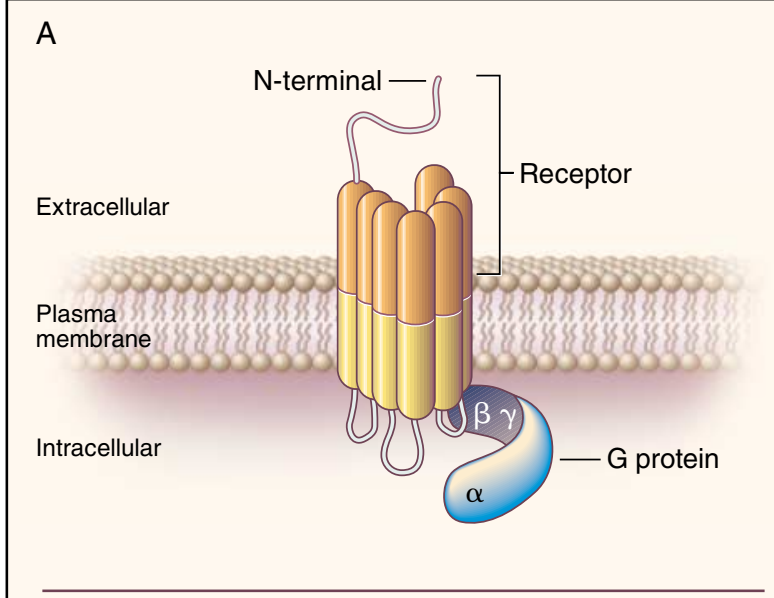

B
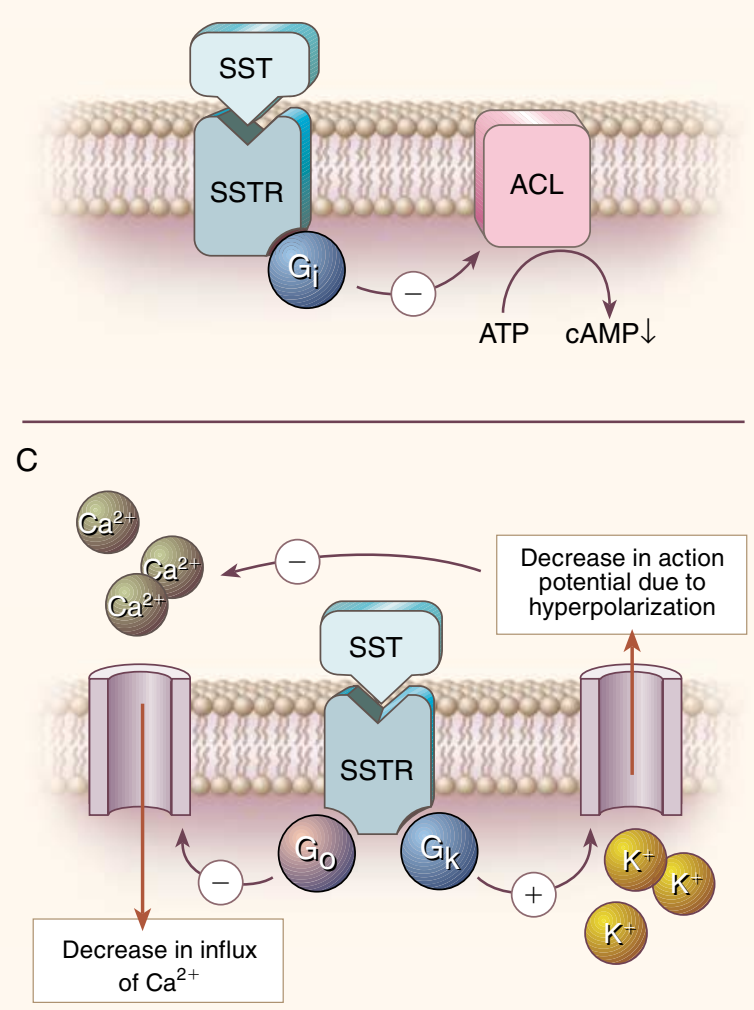

D

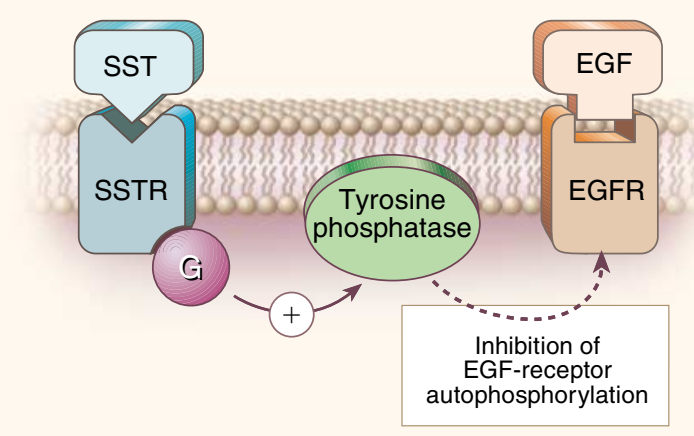

Figure 1. Model of the Effector Systems Coupled to Somatostatin Receptors.

Panel A shows a general model of a receptor coupled to G protein. Somatostatin receptors belong to this superfamily of receptors with seven membrane-spanning domains. The Greek letters denote the protein subunits. Panel $B$ shows the coupling of the somatostatin receptor (SSTR) to adenylate cyclase (ACL). Activation of the receptor may result in a reduction (minus sign) in intracellular cyclic AMP (cAMP) concentrations through the inhibition (minus sign) of adenylate cyclase. SST denotes somatostatin, and $G_{i}$ inhibitory $G$ protein. Panel $C$ shows the coupling of the somatostatin receptor to ion channels. Activation of the receptor may result in a decrease in the influx of calcium $\left(\mathrm{Ca}^{2+}\right)$, either directly through the inhibition of calcium channels or indirectly through a stimulatory effect (plus sign) on the efflux of potassium $\left(K^{+}\right) . G_{0}$ and $G_{k}$ denote $G_{0}$ protein and $G_{k}$ protein, respectively. Panel $D$ shows the coupling of the somatostatin receptor to tyrosine phosphatase. Activation of the receptor may result in the stimulation (plus sign) of tyrosine phosphatase activity. This effect is thought to be involved in the antimitotic actions of somatostatin and its analogues by reversing epidermal growth factor (EGF)-induced phosphorylation of EGF-receptor (EGFR) tyrosine kinase (dashed arrow). ${ }^{20} \mathrm{G}$ denotes $\mathrm{G}$ protein.

(about $\$ 7,800$ annually for a daily dose of $300 \mu \mathrm{g}$ ) must also be considered.

\section{Thyrotropin-Secreting Pituitary Adenomas}

Most thyrotropin-secreting pituitary adenomas express somatostatin receptors..$^{44}$ In a group of 33 patients with this type of tumor, 30 (91 percent) had a response to short-term treatment with octreotide (100 to $300 \mu \mathrm{g}$ daily), with a decrease in thyrotropin secretion, and serum thyroxine concentrations declined to normal values in 73 percent of the patients. ${ }^{44}$

\section{Nonsecretory Pituitary Adenomas}

Most nonsecretory pituitary tumors express somatostatin receptors. ${ }^{45}$ Therapy with octreotide seldom results in a reduction in the size of the tumor, but 30 to 40 percent of patients have improvement in visual-field defects within days after the initiation of treatment. ${ }^{46}$ This response may reflect a direct effect of octreotide on the retina or optic nerve. These studies have been carried out with doses of octreotide ranging from 300 to $1500 \mu \mathrm{g}$ per day, and no particular dose can be recommended at present.

\section{Corticotropin-Secreting Pituitary Adenomas}

No somatostatin receptors have been found on corticotropin-secreting pituitary adenomas in patients with Cushing's disease. ${ }^{38}$ However, most other tumors that secrete corticotropin, such as bronchial and thymic carcinoids, pancreatic islet-cell tumors, and medullary thyroid carcinomas, express somatostatin receptors, and octreotide controls hormonal secretion in some patients with these tumors. ${ }^{38,47}$

\section{Pancreatic Islet-Cell Tumors}

Pancreatic islet-cell tumors retain characteristics of the cells from which they originate, and more than 80 percent of these tumors express somatostatin receptors. ${ }^{6}$ Most are slowly growing malignant tumors that have 


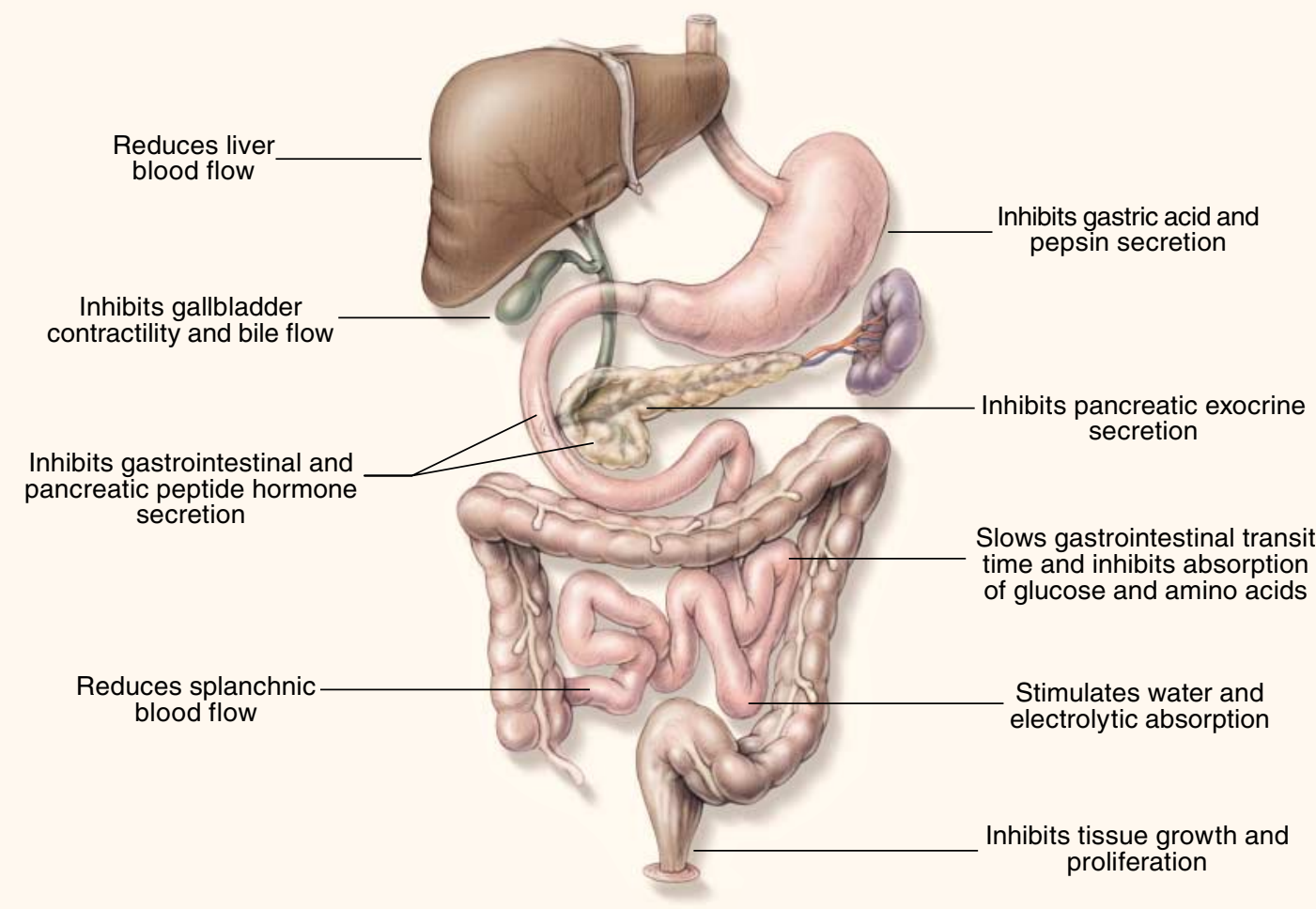

Figure 2. Gastrointestinal Actions of Natural Somatostatin-14. Data were obtained from Reichlin ${ }^{3}$ and Harris. ${ }^{55}$

metastasized at the time of diagnosis, but their clinical manifestations are largely related to hormonal hypersecretion. Treatment with octreotide ameliorates many of the clinical problems — for example, diarrhea, dehydration, and hypokalemia in patients with tumors secreting vasoactive intestinal polypeptide and peptic ulceration, hypoglycemic attacks, and necrolytic skin lesions in patients with tumors secreting gastrin, insulin, and glucagon, respectively. ${ }^{48,49}$ Clinical improvement occurs in 50 to 85 percent of patients during treatment with 150 to $300 \mu \mathrm{g}$ of octreotide per day and is mediated both by a direct inhibitory effect on hormone production by the tumor and by indirect effects - for example, on the resorption of intestinal fluid, the production of hydrochloric acid, or intestinal contractility. ${ }^{48,49}$

Octreotide is especially valuable in the control of symptoms associated with vipomas or glucagonomas. There is little or no effect on tumor growth, however, and after weeks to months of treatment with octreotide, symptoms worsen and hormone secretion by the tumor increases in virtually all patients. ${ }^{50}$ This effect can initially be reversed by increasing the dose of octreotide, but eventually the drug is ineffective in all patients. The loss of sensitivity of endocrine cancers to octreotide is probably associated with the growth of clones of tumor cells that lack somatostatin receptors rather than with a transient down-regulation of these receptors. ${ }^{28,51}$ In patients with gastrinomas, symptoms can often be controlled with histamine $\mathrm{H}_{2}$-receptor-blocking drugs or proton-pump inhibitors. Most insulinomas express somatostatin-14 and somatostatin-28 receptors, but in about 50 percent of patients, these tumors express receptor subtypes that do not bind octreotide. ${ }^{31}$

\section{Carcinoid Tumors}

As with growth hormone-secreting pituitary adenomas, the number of somatostatin receptors on carcinoid tumors determines the suppressive effect of long-term octreotide therapy on hormonal hypersecretion by the tumors. $^{52}$ Control of the symptoms, such as diarrhea and flushing attacks, caused by an overproduction of serotonin or tachykinin has been reported in 70 to 90 percent of patients with metastatic carcinoid tumors. ${ }^{53}$ Octreotide may also temporarily inhibit tumor growth, and in about 20 percent of patients, enlarged lymph nodes and liver metastases shrink. ${ }^{53}$ Most important, however, is the improvement in the quality of life during octreotide therapy, and preliminary evidence suggests that such therapy may prolong survival. ${ }^{54}$

\section{GASTROINTESTINAL INDICATIONS}

Since natural somatostatin inhibits a wide variety of physiologic regulatory functions in the gastrointestinal tract, as well as in the exocrine and endocrine pancreas (Fig. 2), 3,55 somatostatin and its analogues have been viewed as potentially useful in patients with a number of gastrointestinal and pancreatic diseases. For example, the physiologic actions of somatostatin suggest that 
its analogues might help control bleeding from a peptic ulcer. In a five-day, double-blind, placebo-controlled trial involving 273 patients, however, there was no difference in the rates of controlled bleeding in the placebo and octreotide groups (71 and 70 percent, respectively). ${ }^{56}$ The rates of surgery and the requirements for blood transfusion were also not influenced by the use of octreotide. ${ }^{56}$ These results indicate that somatostatin and its analogues are not effective in the treatment of bleeding from a peptic ulcer.

The use of a somatostatin analogue has been beneficial, however, in the control of bleeding from esophageal varices. ${ }^{57,58} \mathrm{In}$ a study of 100 patients, the effect of injection sclerotherapy in the treatment of acute variceal hemorrhage was compared with that of octreotide $(50 \mu \mathrm{g}$ given as an intravenous bolus dose followed by a continuous infusion of $50 \mu \mathrm{g}$ per hour for 48 hours).$^{59}$ At the end of the 48-hour study period, the patients receiving octreotide also received sclerotherapy to obliterate the varices. ${ }^{59}$ Octreotide therapy and emergency sclerotherapy were equally effective in the acute control of variceal bleeding. This study suggests that octreotide can be administered when injection sclerotherapy is not available and is probably also useful for recurrent bleeding after sclerotherapy.

Somatostatin inhibits exocrine pancreatic secretion. 3,55 Somatostatin analogues might therefore be expected to be of benefit in disorders in which the pancreatic-duct flow is compromised. In four placebo-controlled trials involving nearly 400 patients, however, neither natural somatostatin nor octreotide improved the course of acute pancreatitis. ${ }^{60}$ Octreotide also did not prevent pain or pancreatitis after endoscopic retrograde cholangiopancreatography. ${ }^{61}$

Octreotide has been administered to reduce fluid production by pancreatic fistulas and pseudocysts. A review of 26 reports on octreotide therapy (100 to $450 \mu \mathrm{g}$ per day) in 68 patients with pancreatic fistulas revealed a considerable reduction in fluid production in virtually all patients, ${ }^{55}$ but it remains uncertain whether octreotide, as compared with surgical intervention and total parenteral nutrition, results in a larger number of closed fistulas or in earlier closure. In two placebo-controlled studies involving nearly 500 patients undergoing elective pancreatic surgery, the patients receiving octreotide (100 $\mu \mathrm{g}$ three times a day for seven days perioperatively) had significantly lower rates of postoperative complications than the patients receiving placebo. ${ }^{62,63}$

Somatostatin prolongs the gastrointestinal transit time, decreases endogenous fluid secretion in the jejunum, and stimulates intestinal absorption of water and electrolytes. ${ }^{3,55}$ Both somatostatin and octreotide (50 to 500 $\mu \mathrm{g}$ per day) improve secretory diarrhea in patients with ileostomies, the short-bowel syndrome, intestinal graftversus-host disease, radiation colitis, or intestinal fistulas. ${ }^{55}$ Patients with the acquired immunodeficiency syndrome (AIDS) may have high-volume watery diarrhea, and in about half these patients enteropathogens such as cryptosporidium can be identified. In two prospective open-label trials involving 110 patients with AIDSrelated diarrhea, a dose of 150 to $1500 \mu \mathrm{g}$ per day for 14 days, a dose determined on the basis of stool volume, induced a complete response in 19 percent of the patients and a partial response, with a 50 percent reduction in stool volume, in 27 percent ${ }^{55,64}$; the patients with responses also had an improved quality of life. In most studies of patients with AIDS and high-volume secretory diarrhea, however, there has been a tendency for diarrhea to recur despite continued treatment with octreotide.

\section{Potential Role in Oncologic Treatment}

Somatostatin analogues inhibit the growth of a variety of tumors in animals. ${ }^{31,65}$ This action may occur as a result of inhibition of the secretion of growth hormone, insulin, and gastrointestinal hormones; direct or indirect (through growth hormone) inhibition of the production of insulin-like growth factor I or its binding proteins; direct inhibition of angiogenesis; or direct antiproliferative effects on tumor cells, mediated by somatostatin receptors.

Like most neuroendocrine tumors, adenocarcinomas originating in the breast, kidney, colon, or ovary, as well as meningiomas, express somatostatin receptors. ${ }^{6,31} \mathrm{De}-$ spite the direct antimitotic effects of somatostatin analogues on some human cancer cell lines positive for somatostatin receptors, ${ }^{31}$ the heterogeneous distribution of somatostatin receptors in many adenocarcinomas suggests that treatment with these analogues will affect only some areas of the tumors, ${ }^{6,31}$ and a role for treatment with a somatostatin analogue in patients with inoperable somatostatin-receptor-positive adenocarcinomas has not been established. ${ }^{31}$ The high density of somatostatin receptors on some tumors, as well as the availability of potent and stable somatostatin analogues as radioligands, has made it possible to use somatostatin-receptor scintigraphy with ${ }^{111}$ In-labeled pentetic acidD-Phe ${ }^{1}$-octreotide for the visualization of somatostatinreceptor-positive cancers. ${ }^{31,66}$

More information about the expression of different subtypes of somatostatin receptors in different cancers should soon be available. As mentioned above, one subtype may be linked to more than one effector system (Table 1 and Fig. 1), and the stimulation of tyrosine phosphatase activity by somatostatin analogues may be linked preferentially to an antimitotic effect. ${ }^{20,26}$ In this respect the differential antihormonal and antimitotic effects of somatostatin-14, octreotide, and lanreotide seem important. ${ }^{20,26,65,67}$ A limited number of studies have demonstrated heterogeneous expression of the various somatostatin-receptor subtypes on human tumors, such as pituitary adenomas, ${ }^{68,69}$ islet-cell tumors, and carcinoids. ${ }^{14,70}$ Further developments in the use of somatostatin analogues in patients with these tumors await the definitive identification of the receptor subtype (or subtypes) mediating the antiproliferative ef- 
fects of somatostatin, as well as the development of one or more analogues that selectively activate the receptor subtype (or subtypes).

\section{Adverse Effects of Octreotide}

Common adverse effects of treatment with octreotide include nausea, abdominal cramps, diarrhea, malabsorption of fat, and flatulence..$^{38,43,55}$ These symptoms start within hours after the first injection of the drug, their severity is dose-dependent, and they usually subside spontaneously in 10 to 14 days, despite continued treatment. The occurrence of these adverse effects can be readily understood from the physiologic actions of somatostatin on the gastrointestinal tract and exocrine pancreas, as shown in Figure 2. The spontaneous resolution of these symptoms supports the concept of a rapid adaptation to the effects of somatostatin on the function of the gastrointestinal tract and pancreas.

Since somatostatin analogues inhibit the secretion of insulin, reduced glucose tolerance and even overt hyperglycemia might be expected during therapy with octreotide..$^{38,43}$ Although the drug has a short-lived inhibitory effect on insulin secretion, its ability to delay the absorption of carbohydrates and inhibit the secretion of growth hormone and glucagon prevents a clinically important effect on carbohydrate metabolism during longterm therapy. ${ }^{36,38,43}$

Long-term treatment with octreotide ( $>1$ month) is associated with an increased incidence of cholesterol gallstones (occurring in approximately 20 to 30 percent of patients). ${ }^{43}$ The prevalence of octreotide-induced gallstones varies geographically and may be influenced by dietary, environmental, or racial factors. ${ }^{71}$ The formation of gallstones during octreotide therapy probably involves inhibition of gallbladder emptying and intestinal motility, inhibition of the secretion of prokinetic peptides such as cholecystokinin, and increased intestinal and biliary production of deoxycholic acid, all of which promote the nucleation of cholesterol crystals and their aggregation into stones. ${ }^{71}$ Because of poor gallbladder emptying, crystals and small stones are not discharged after meals. Fortunately, in most cases the gallstones remain asymptomatic: only approximately 1 percent of patients have symptoms per year of treatment. ${ }^{43}$

\section{New Forms of Somatostatin Analogues}

Octreotide has to be administered subcutaneously two or three times daily. A long-acting form that has recently been developed consists of 20 to $30 \mathrm{mg}$ of octreotide mixed with microspheres of DL-lactide-co-glycolide polymer. ${ }^{72}$ In most patients with acromegaly, an intramuscular injection of this preparation controls growth hormone hypersecretion for 28 to 42 days as effectively as do multiple daily subcutaneous injections (Fig. 3). A long-acting intramuscular formulation of lanreotide also controls growth hormone secretion in patients with
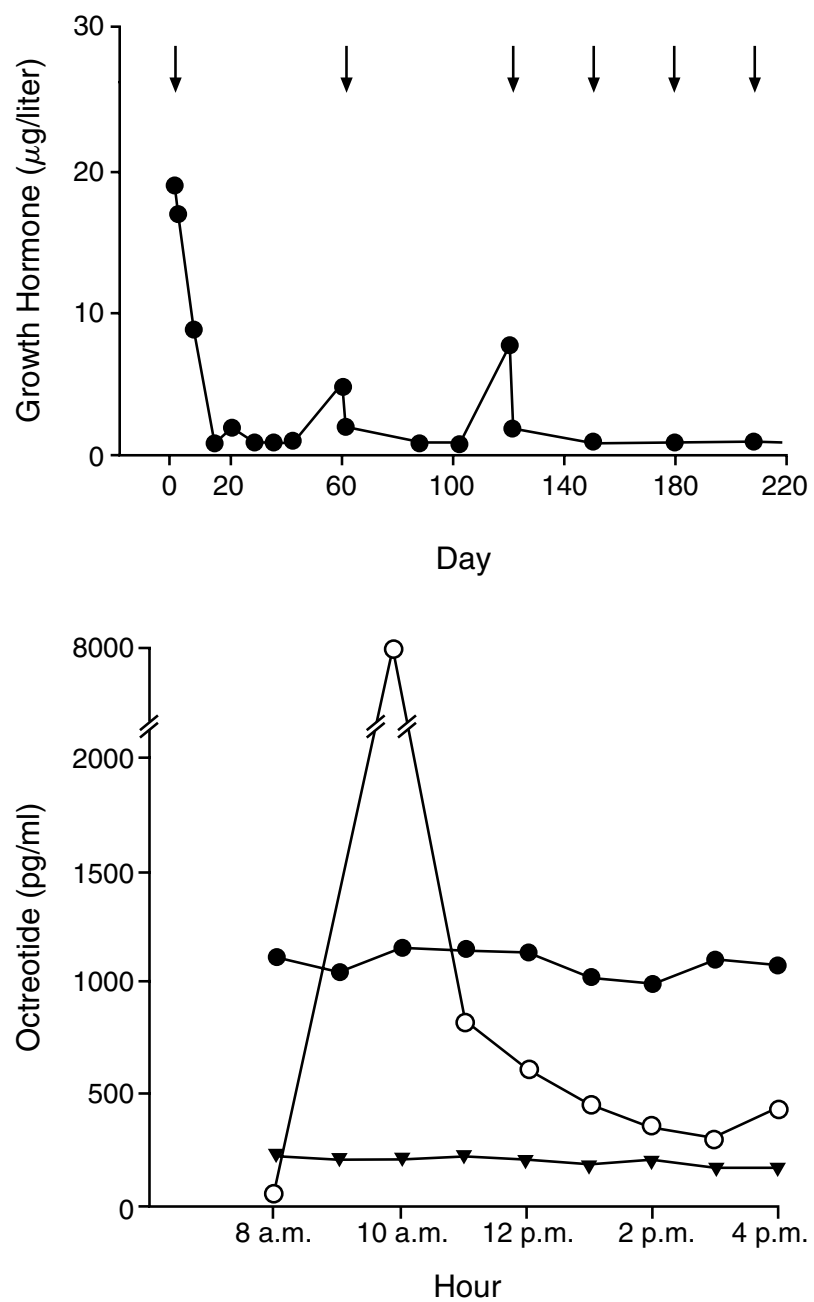

Figure 3. Serum Growth Hormone and Plasma Octreotide Concentrations in a Patient with Acromegaly Treated with a LongActing Formulation of Octreotide.

The upper panel shows the effect of the intramuscular depot administration of $30 \mathrm{mg}$ of octreotide on mean serum growth hormone concentrations. Each point represents the mean concentration in eight blood samples, collected every hour between 8 a.m. and 4 p.m. on the day indicated. The arrows indicate the injections. The control of growth hormone secretion was improved after an increase in the frequency of injections to once a month (starting with the third injection).

The lower panel shows the plasma octreotide concentrations between 8 a.m. and 4 p.m. on day 60 after the first injection $(\boldsymbol{\nabla})$ and on day 148, 28 days after the third injection ( $)$. The plasma octreotide concentrations after $100 \mu \mathrm{g}$ of octreotide had been administered subcutaneously at 8:15 a.m., before the start of the intramuscular depot injections, are also shown (O). (The plasma octreotide values were determined by Dr. I. Lancranjan. ${ }^{72}$ )

acromegaly, but its duration of action is two weeks at most. ${ }^{73}$

\section{Conclusions}

The clinical introduction of somatostatin analogues has resulted in new insights into the physiology of a number of organ systems. Despite the broad range of 
physiologic actions of somatostatin, its analogues control hormonal hypersecretion by somatostatin-receptor-positive endocrine tumors without serious side effects. The subtypes of somatostatin receptors on these tumors may turn over at a different rate from those on normal tissue. Therefore, the inhibitory effects of octreotide on hormonal hypersecretion by endocrine tumors persist, whereas adaptation occurs in most normal somatostatin target tissues, thus preventing serious side effects. These considerations form the basis for the list of established, probable, and unestablished indications for the use of somatostatin analogues (Table 2). Octreotide represents an important advance in the medical management of pituitary adenomas secreting growth hormone or thyrotropin, as well as in the treatment of carcinoid tumors and inoperable islet-cell carcinomas secreting vasoactive intestinal polypeptide or glucagon. Treatment with octreotide offers a substantial improvement in the quality of life among patients with these diseases.

All functions of the gastrointestinal tract and the exocrine pancreas are regulated by a multitude of local factors, including a variety of peptide hormones. ${ }^{74}$ Pharmacologic amounts of somatostatin analogues initially inhibit a number of regulatory functions, but this response is followed by local adaptation. On the one hand, this adaptation is fortunate, because long-term therapy usually causes only transient side effects. On the other hand, local adaptation precludes a persistent benefit of somatostatin and its analogues in the longterm treatment of patients with functional abnormalities of the gastrointestinal tract and the pancreas. This adaptation to the inhibitory effects of octreotide has been well documented in studies in normal subjects. ${ }^{75,76}$ After seven days of treatment with octreotide (100 to

Table 2. Established, Probable, and Unestablished Indications for the Use of Somatostatin Analogues.

\footnotetext{
Established indications

Pituitary adenomas secreting growth hormone or thyrotropin that recur after surgery

Metastatic islet-cell tumors, especially vipomas and glucagonomas

Metastatic carcinoid tumors

Somatostatin-receptor scintigraphy of somatostatinreceptor-positive diseases

Probable indications

Acute esophageal variceal bleeding, especially if sclerotherapy is not available or has failed

Pancreatic and enteric fistulas

Prevention of complications after elective pancreatic surgery

Secretory diarrhea

AIDS-related diarrhea

Unestablished indications

Other somatostatin-receptor-positive neuroendocrine tumors and adenocarcinomas

Upper gastrointestinal bleeding

Pancreatitis induced by endoscopic retrograde cholangiopancreatography
}

$300 \mu \mathrm{g}$ per day), the initial inhibitory effects on the secretion of gastric acid, amylase, trypsin, and lipase diminish or disappear. Nevertheless, short-term therapy with octreotide is beneficial in patients undergoing elective pancreatic surgery and in those with variceal bleeding, intestinal fistulas, or secretory diarrhea (Table 2).

More knowledge about the subtypes of somatostatin receptors that account for the antimitotic actions of somatostatin, studies of the expression of these receptor subtypes in different tumors, and the development of subtype-specific somatostatin analogues may eventually result in new palliative treatments for patients with a variety of tumors.

The benefits of treatment with somatostatin analogues must always be weighed against the risk of adverse effects associated with long-term treatment notably, the development of gallstones. The high cost of treatment should also be considered. The recent development of a long-acting depot preparation of octreotide should make therapy much easier, and further improvement in analogue formulations and the specificity of their action can be anticipated.

\section{REFERENCES}

1. Krulich L, Dhariwal APS, McCann SM. Stimulatory and inhibitory effects of purified hypothalamic extracts on growth hormone release from rat pituitary in vitro. Endocrinology 1968;83:783-90.

2. Brazeau P, Vale WW, Burgus R, et al. Hypothalamic polypeptide that inhibits the secretion of immunoreactive pituitary growth hormone. Science 1973;179:77-9.

3. Reichlin S. Somatostatin. N Engl J Med 1983;309:1495-501, 1556-63.

4. Patel YC. General aspects of the biology and function of somatostatin. In: Basic clinical aspects of neuroscience. Vol. 4. Heidelberg, Germany: Springer-Verlag, 1992.

5. Reichlin S. Neuroendocrine-immune interactions. N Engl J Med 1993;329: 1246-53.

6. Reubi JC, Kvols L, Krenning E, Lamberts SWJ. Distribution of somatostatin receptors in normal and tumor tissue. Metabolism 1990;39:Suppl 2:7881

7. Reubi JC, Waser B, Horisberger U, et al. In vitro autoradiographic and in vivo scintigraphic localization of somatostatin receptors in human lymphatic tissue. Blood 1993;82:2143-51.

8. Yamada Y, Post SR, Wang K, Tager HS, Bell GI, Seino S. Cloning and functional characterization of a family of human and mouse somatostatin receptors expressed in brain, gastrointestinal tract, and kidney. Proc Natl Acad Sci U S A 1992;89:251-5.

9. Yamada Y, Reisine T, Law SF, et al. Somatostatin receptors, an expanding gene family: cloning and functional characterization of human SSTR3, a protein coupled to adenylyl cyclase. Mol Endocrinol 1992;6:2136-42.

10. Bruno JF, Xu Y, Song J, Berelowitz M. Molecular cloning and functional expression of a brain-specific somatostatin receptor. Proc Natl Acad Sci U S A 1992;89:11151-5.

11. O'Carroll AM, Lolait SJ, Konig M, Mahan LC. Molecular cloning and expression of a pituitary somatostatin receptor with preferential affinity for somatostatin-28. Mol Pharmacol 1992;42:939-46. [Erratum, Mol Pharmacol 1993;44:1278.]

12. Patel YC, Srikant CB. Subtype selectivity of peptide analogs for all five cloned human somatostatin receptors (hsstr 1-5). Endocrinology 1994;135: 2814-7.

13. Bruns C, Weckbecker G, Raulf F, et al. Molecular pharmacology of somatostatin-receptor subtypes. Ann N Y Acad Sci 1994;733:138-46.

14. Kubota A, Yamada Y, Kagimoto S, et al. Identification of somatostatin receptor subtypes and an implication for the efficacy of somatostatin analogue SMS 201-995 in treatment of human endocrine tumors. J Clin Invest 1994; 93:1321-5.

15. Kaupmann K, Bruns C, Hoyer D, Seuwen K, Lubbert H. Distribution and second messenger coupling of four somatostatin receptor subtypes expressed in brain. FEBS Lett 1993;331:53-9.

16. Rohrer L, Raulf F, Bruns C, Buettner R, Hofstaedter F, Schule R. Cloning and characterization of a fourth human somatostatin receptor. Proc Natl Acad Sci U S A 1993;90:4196-200. 
17. Panetta R, Greenwood MT, Warszynska A, et al. Molecular cloning, functional characterization, and chromosomal localization of a human somatostatin receptor (somatostatin receptor type 5) with preferential affinity for somatostatin-28. Mol Pharmacol 1994;45:417-27.

18. O'Carroll AM, Raynor K, Lolait SJ, Reisine T. Characterization of cloned human somatostatin receptor SSTR5. Mol Pharmacol 1994;46:291-8.

19. Bell GI, Reisine T. Molecular biology of somatostatin receptors. Trends Neurosci 1993;16:34-8.

20. Liebow C, Reilly C, Serrano M, Schally AV. Somatostatin analogues inhibit growth of pancreatic cancer by stimulating tyrosine phosphatase. Proc Natl Acad Sci U S A 1989;86:2003-7.

21. Yasuda K, Rens-Domiano S, Breder CD, et al. Cloning of a novel somatostatin receptor, SSTR3, coupled to adenylylcyclase. J Biol Chem 1992;267: 20422-8.

22. Raynor K, O'Carroll A-M, Kong H, et al. Characterization of cloned somatostatin receptors SSTR4 and SSTR5. Mol Pharmacol 1993;44:385-92.

23. Patel YC, Greenwood MT, Warszynska A, Panetta R, Srikant CB. All five cloned human somatostatin receptors (hSSTR1-5) are functionally coupled to adenylyl cyclase. Biochem Biophys Res Commun 1994;198:605-12.

24. Patel YC, Murthy KK, Escher EE, Banville D, Spiess J, Srikant CB. Mech anism of action of somatostatin: an overview of receptor function and studies of the molecular characterization and purification of somatostatin receptor proteins. Metabolism 1990;39:Suppl 2:63-9.

25. Akbar M, Okajima F, Tomura $\mathrm{H}$, et al. Phospholipase $\mathrm{C}$ activation and $\mathrm{Ca}^{2+}$ mobilization by cloned human somatostatin receptor subtypes $1-5$, in transfected COS-7 cells. FEBS Lett 1994;348:192-6.

26. Buscail L, Delesque N, Esteve JP, et al. Stimulation of tyrosine phosphatase and inhibition of cell proliferation by somatostatin analogues: mediation by human somatostatin receptor subtypes SSTR1 and SSTR2. Proc Natl Acad Sci U S A 1994;91:2315-9.

27. Buscail L, Estève JP, Saint-Laurent N, et al. Inhibition of cell proliferation by the somatostatin analogue RC-160 is mediated by somatostatin receptor subtypes SSTR2 and SSTR5 through different mechanisms. Proc Natl Acad Sci U S A 1995;92:1580-4.

28. Guillemin R. Peptides in the brain: the new endocrinology of the neuron Science 1978;202:390-402.

29. Bauer W, Briner U, Doepfner W, et al. SMS 201-995: a very potent and selective octapeptide analogue of somatostatin with prolonged action. Life Sci 1982;31:1133-40.

30. Lamberts SWJ, Oosterom R, Neufeld M, del Pozo E. The somatostatin analog SMS 201-995 induces long-acting inhibition of growth hormone secretion without rebound hypersecretion in acromegalic patients. J Clin Endocrinol Metab 1985;60:1161-5.

31. Lamberts SWJ, Krenning EP, Reubi JC. The role of somatostatin and its analogs in the diagnosis and treatment of tumors. Endocr Rev 1991;12:450-82.

32. Hofland LJ, van Koetsveld PM, Waaijers M, Zuyderwijk J, Lamberts SWJ. Relative potencies of the somatostatin analogs octreotide, BIM-23014, and $\mathrm{RC}-160$ on the inhibition of hormone release by cultured human endocrine tumor cells and normal rat anterior pituitary cells. Endocrinology 1994;134: 301-6.

33. Rossowski WJ, Coy DH. Specific inhibition of rat pancreatic insulin or glucagon release by receptor-selective somatostatin analogs. Biochem Biophys Res Commun 1994;205:341-6.

34. Reubi JC, Landolt AM. The growth hormone responses to octreotide in acromegaly correlate with adenoma somatostatin receptor status. J Clin Endocrinol Metab 1989;68:844-50.

35. Lamberts SWJ, Uitterlinden P, Verschoor L, van Dongen KJ, del Pozo E. Long-term treatment of acromegaly with the somatostatin analogue SMS 201-995. N Engl J Med 1985;313:1576-80.

36. Lamberts SWJ, Uitterlinden P, Schuijff PC, Klijn JG. Therapy of acromegaly with sandostatin: the predictive value of an acute test, the value of serum somatostatin- $\mathrm{C}$ measurements in dose adjustment and the definition of a biochemical 'cure.' Clin Endocrinol (Oxf) 1988;29:411-20.

37. Ezzat S, Snyder PJ, Young WF, et al. Octreotide treatment of acromegaly: a randomized, multicenter study. Ann Intern Med 1992;117:711-8.

38. Lamberts SWJ. The role of somatostatin in the regulation of anterior pituitary hormone secretion and the use of its analogs in the treatment of human pituitary tumors. Endocr Rev 1988;9:417-36.

39. Lamberts SWJ, Zweens M, Verschoor L, del Pozo E. A comparison among the growth hormone-lowering effects in acromegaly of the somatostatin analog SMS 201-995, bromocriptine, and the combination of both drugs. J Clin Endocrinol Metab 1986;63:16-9.

40. Wagenaar AH, Harris AG, van der Lely AJ, Lamberts SWJ. Dynamics of the acute effects of octreotide, bromocriptine and both drugs in combination on growth hormone secretion in acromegaly. Acta Endocrinol (Copenh) 1991; 125:637-42.

41. Lamberts SWJ, Zweens M, Klijn JGM, van Vroonhoven CC, Stefanko SZ, Del Pozo E. The sensitivity of growth hormone and prolactin secretion to the somatostatin analogue SMS 201-995 in patients with prolactinomas and acromegaly. Clin Endocrinol (Oxf) 1986;25:201-12.
42. van der Lely AJ, Harris AG, Lamberts SWJ. The sensitivity of growth hormone secretion to medical treatment in acromegalic patients: influence of age and sex. Clin Endocrinol (Oxf) 1992;37:181-5.

43. Acromegaly Therapy Consensus Development Panel. Benefits versus risks of medical therapy for acromegaly. Am J Med 1994;97:468-73.

44. Chanson P, Weintraub BD, Harris AG. Octreotide therapy for thyroid-stimulating hormone-secreting pituitary adenomas: a follow-up of 52 patients. Ann Intern Med 1993;119:236-40.

45. de Bruin TWA, Kwekkeboom DJ, Van't Verlaat JW, et al. Clinically nonfunctioning pituitary adenoma and octreotide response to long term high dose treatment, and studies in vitro. J Clin Endocrinol Metab 1992;75:1310-7.

46. Warnet A, Timsit J, Chanson P, et al. The effect of somatostatin analogue on chiasmal dysfunction from pituitary macroadenomas. J Neurosurg 1989; 71:687-90.

47. de Herder WW, Krenning EP, Malchoff CD, et al. Somatostatin receptor scintigraphy: its value in tumor localization in patients with Cushing's syndrome caused by ectopic corticotropin or corticotropin-releasing hormone secretion. Am J Med 1994;96:305-12.

48. Kvols LK, Buck M, Moertel CG, et al. Treatment of metastatic islet cell carcinoma with a somatostatin analogue (SMS 201-995). Ann Intern Med $1987 ; 107: 162-8$

49. Neuroendocrine disorders of the gastroenteropancreatic system: clinical applications of the somatostatin analogue SMS 201-995: April 2-4, 1986, San Diego, California. Am J Med 1986;81:1-101.

50. Wynick D, Anderson JV, Williams SJ, Bloom SR. Resistance to metastatic pancreatic endocrine tumours after long-term treatment with the somatostatin analogue octreotide (SMS 201-995). Clin Endocrinol (Oxf) 1989;30: $385-8$.

51. Lamberts SWJ, Pieters GFFM, Metselaar HJ, Ong GL, Tan HS, Reubi J-C. Development of resistance to a long-acting somatostatin analogue during treatment of two patients with metastatic endocrine pancreatic tumours. Acta Endocrinol (Copenh) 1988;119:561-6.

52. Reubi JC, Kvols LK, Waser B, et al. Detection of somatostatin receptors in surgical and percutaneous needle biopsy samples of carcinoids and islet cell carcinomas. Cancer Res 1990;50:5969-77.

53. Kvols LK, Moertel CG, O'Connell MJ, Schutt AJ, Rubin J, Hahn RG. Treatment of the malignant carcinoid syndrome: evaluation of a long-acting somatostatin analogue. N Engl J Med 1986;315:663-6.

54. Kvols LK. Metastatic carcinoid tumors and the malignant carcinoid syndrome. Ann N Y Acad Sci 1994;733:464-70.

55. Harris AG. Octreotide in the treatment of disorders of the gastrointestinal tract. Drug Invest 1992;4:1-54.

56. Christiansen J, Ottenjann R, Von Arx F. Placebo-controlled trial with the somatostatin analogue SMS 201-995 in peptic ulcer bleeding. Gastroenterology 1989;97:568-74.

57. Valenzuela JE, Schubert T, Fogel MR, et al. A multicenter, randomized, double-blind trial of somatostatin in the management of acute hemorrhage from esophageal varices. Hepatology 1989;10:958-61.

58. Burroughs AK, McCormick PA, Hughes MD, Sprengers D, D'Heygere F, McIntyre N. Randomized, double-blind, placebo-controlled trial of somatostatin for variceal bleeding: emergency control and prevention of early variceal rebleeding. Gastroenterology 1990;99:1388-95.

59. Sung JJY, Chung SCS, Lai C-W, et al. Octreotide infusion or emergency sclerotherapy for variceal haemorrhage. Lancet 1993;342:637-41.

60. McKay CJ, Imrie CW, Baxter JN. Somatostatin and somatostatin analogues - are they indicated in the management of acute pancreatitis? Gut 1993; 34:1622-6.

61. Binmoeller KF, Harris AG, Dumas R, Grimaldi C, Delmont JP. Does the somatostatin analogue octreotide protect against ERCP induced pancreatitis? Gut 1992;33:1129-33.

62. Buchler M, Friess H, Klempa I, et al. Role of octreotide in the prevention of postoperative complications following pancreatic resection. Am J Surg 1992;163:125-31.

63. Bassi C, Falconi M, Lombardi D, et al. Prophylaxis of complications after pancreatic surgery: results of a multicenter trial in Italy. Digestion 1994;55: Suppl 1:41-7.

64. Cello JP, Grendell JH, Basuk P, et al. Effect of octreotide on refractory AIDS-associated diarrhea: a prospective multicenter clinical trial. Ann Intern Med 1991;115:705-10.

65. Schally AV. Oncological applications of somatostatin analogues. Cancer Res 1988;48:6977-85. [Erratum, Cancer Res 1989;49:1618.]

66. Krenning EP, Bakker WH, Breeman WAP, et al. Localisation of endocrinerelated tumours with radioiodinated analogue of somatostatin. Lancet 1989; $1: 242-4$.

67. Hofland LJ, van Koetsveld PM, Wouters N, Waaijers M, Reubi JC, Lamberts SWJ. Dissociation of antiproliferative and antihormonal effects of the somatostatin analog octreotide on $7315 \mathrm{~b}$ pituitary tumor cells. Endocrinology 1992;131:571-7.

68. Greenman Y, Melmed S. Heterogeneous expression of two somatostatin receptor subtypes in pituitary tumors. J Clin Endocrinol Metab 1994;78:398-403. 
69. Idem. Expression of three somatostatin receptor subtypes in pituitary adenomas: evidence for preferential SSTR5 expression in the mammosomatotroph lineage. J Clin Endocrinol Metab 1994;79:724-9.

70. Reubi J-C, Schaer JC, Waser B, Mengod G. Expression of localization of somatostatin receptor SSTR1, SSTR2, and SSTR3 messenger RNAs in primary human tumors using in situ hybridization. Cancer Res 1994;54:3455-9.

71. Dowling RH, Hussaini SH, Murphy GM, Besser GM, Wass JAH. Gallstones during octreotide therapy. Metabolism 1992;41:Suppl 2:22-33.

72. Lancranjan I, Bruns C, Grass P, et al. Sandostatin LAR: pharmacokinetics, pharmacodynamics, efficacy, and tolerability in acromegalic patients. Metabolism 1995;44:Suppl 1:18-26.
73. Heron I, Thomas F, Dero M, et al. Pharmacokinetics and efficacy of a longacting formulation of the new somatostatin analog BIM 23014 in patients with acromegaly. J Clin Endocrinol Metab 1993;76:721-7.

74. Delvalle J, Yamada T. The gut as an endocrine organ. Annu Rev Med 1990; 41:447-55.

75. Creutzfeldt W, Lembcke B, Folsch UR, Schleser S, Koop I. Effect of somatostatin analogue (SMS 201-995, Sandostatin) on pancreatic secretion in humans. Am J Med 1987;82:49-59.

76. Londong W, Angerer M, Kutz K, Landgraf R, Londong V. Diminishing efficacy of octreotide (SMS 201-995) on gastric functions of healthy subjects during one-week administration. Gastroenterology 1989;96:713-22. 